\title{
Developing an Apprenticeship Assessment Tool to Improve the Competitiveness of Fashion Design Graduates
}

\author{
A H S Irianti ${ }^{1}$, N Aini ${ }^{2}$, S E P Rahayu ${ }^{3}$ \\ ${ }^{1}$ Department of Industrial Technology, Faculty of Engineering, State University of \\ Malang (Universitas Negeri Malang), Jl Semarang 5 Malang, Indonesia. \\ ${ }^{2}$ Department of Industrial Technology, Faculty of Engineering, State University of \\ Malang (Universitas Negeri Malang), Jl Semarang 5 Malang, Indonesia. \\ ${ }^{3}$ Department of Industrial Technology, Faculty of Engineering, State University of \\ Malang (Universitas Negeri Malang), Jl Semarang 5 Malang, Indonesia. \\ Corresponding author: agus.hery.ft@um.ac.id
}

\begin{abstract}
The performance of Fashion Design students during apprenticeship is commonly assessed using the letter grading system (A, A-, B +, B, B-, C +, C, D, and $\mathrm{E})$. This form of assessment is considered irrelevant to the demands of the current job market. Graduates are required to have high competitiveness. Apprenticeship is a training programme that offers hands-on experience and adds value to graduates. However, apparently, such assessment cannot create a significant beneficial impact on generating competitive graduates. This research and development $(\mathrm{R} \& \mathrm{D})$ project was conducted following the five phases of the ADDIE model, i.e. analysis, design, development, implementation, and evaluation. This research aimed at developing an apprenticeship assessment instrument as an attempt to improve the competitiveness of graduates. In addition to the letter grades for transcript purposes, a form of narrative assessment was developed to describe student performance accurately during apprenticeship. The assessment tool was validated by experts and tried out on Fashion Design students.
\end{abstract}

Keywords: assessment tool, apprenticeship, competitiveness

\section{Introduction}

Competitiveness is highly essential for Fashion Design graduates. One way to support graduate competitiveness is by carrying out a proper assessment of student performance during apprenticeship and the results of which are presented in the Diploma Supplement (DS) or Surat Keterangan Pendamping Ijazah (SKPI). The Diploma Supplement is an official statement issued by higher education institutions which accompanies a higher education diploma and contains a record of academic achievement or qualification presented in narrative form. This document provides a description of additional details relating to completed qualifications based on the Indonesian Qualification Framework (KKNI) in a standardised format that is easily understood by general public [1]. In fact, the DS serves to showcase student skills gained during apprenticeship so as to attain recognition in the world of work. However, the assessment methods that have been 
used cannot precisely display various competencies acquired by students during the apprenticeship programme. Higher education institutions should not only be able to equip students with practical knowledge and professional skills but also provide a tool for promoting students' qualifications to improve their competitiveness [2].

Students usually undertake an apprenticeship programme for 2-6 months. The apprenticeship assessment includes performance evaluation by worksite mentors and final report marking by supervising lecturers; student achievement is represented only by numerical scores. The industry should be involved in issuing certificates of competence for students completing the apprenticeship. Higher education institutions should rely not only on scores and grades but also narrative descriptions to provide detailed information on student achievement and competencies. Combinations of scores or numerical scales cannot capture every single practical skill a student develops during apprenticeship. In fact, different students can acquire different skills, and thus scores and grades cannot give a precise description of their competencies.

Student achievement in the apprenticeship programme is determined based on an assessment by an apprenticeship mentor, a supervising lecturer, and the combination of both. Evaluation by the worksite mentor includes the following aspects: (1) work quality, (2) work speed, (3) occupational safety, (4) working knowledge, (5) work attitude, (6) work discipline and (7) creativity at work. Each aspect is assessed based on the following grading categories: excellent (80-100), good (7079), satisfactory (60-69), and fair (55-59). Evaluation by the supervising lecturers is carried out by assessing the student's final report based on the following components: (1) organisation, (2) completeness and (3) mechanics. The letter grading system used consists of seven grades, i.e. A (85-100), A- (80-84), B+ (75-79), B (70-74), B- (65-69), C+ (60-64) and C (55-59). Lastly, student achievement in the apprenticeship course is represented by a combination between the assessment by worksite mentor and supervising lecturer or so-called the final score; the final score is obtained by integrating the results of the two assessment methods above and then being divided by five.

\section{Literature Review}

1. Competitiveness of Fashion Design Graduates

Competitiveness is the outcome of the ability to innovate to maintain a favourable position [3]. Innovation is often associated with competitiveness because competitiveness is tied to human resources [4]. Unfortunately, student competencies have not been properly showcased. Human resources play an integral role in competitiveness by making a significant contribution [5]. Competitiveness can also be said to be the result of an advantage owned by an environment to produce something better [6]. Higher education is a key component that can contribute to the competitiveness in the world of work because universities are the drivers of innovation. In today's global era, competitiveness becomes a critical requirement for graduates, and Fashion Design graduates are no exception. One of the effective solutions to increase competitiveness in Fashion Design graduates is by developing the Diploma Supplement.

Graduates with the degree of Fashion Design can work in several areas such as garment, boutique, tailor and modiste [7]. However, the competitiveness of graduates is relatively low. Factors that cause the low competitiveness of graduates is the absence of information about academic career and competencies gained during lessons, particularly the apprenticeship course for 2-6 months. In fact, a comprehensive record of qualifications is very useful for improving competitiveness. The description of competencies will be presented in the Diploma Supplement. The Diploma Supplement has been fully implemented in some countries all around the world. However, it was just introduced in Indonesia in 2014; it is even used only in 
a few universities. On top of that, many universities issue the Diploma Supplement only if the students make a request.

2. Assessment of Fashion Design Student Performance During Apprenticeship

The apprenticeship course is usually 2-6 months long. Student performance is commonly evaluated using a typical quantitative assessment system; student performance is associated with letter and number grades: A to E, corresponding to numerical scores ranging from 0-100. In evaluating student performance during apprenticeship, however, grades $\mathrm{A}$ to $\mathrm{C}(\mathrm{A}, \mathrm{A}-, \mathrm{B}+$, $\mathrm{B}, \mathrm{B}-, \mathrm{C}+$ and $\mathrm{C}$ ) are used. Student achievement in the apprenticeship programme is determined based on an assessment by an apprenticeship mentor, a supervising lecturer, and the combination of both which generate a final score.

Evaluation by the worksite mentor includes the following aspects: (1) work quality, (2) work speed, (3) occupational safety, (4) working knowledge, (5) work attitude, (6) work discipline and (7) creativity at work. Each aspect is assessed based on the following grading categories: excellent (80-100), good (70-79), satisfactory (60-69), and fair (55-59).

Evaluation by the supervising lecturers is carried out by assessing the student's final report based on the following components: (1) organisation, (2) completeness and (3) mechanics. The completeness of the report is judged based on two aspects: general (management organisation) and specific (relevance to study programme); the proportion of the general aspect is $40 \%$, that of the specific aspect is $60 \%$. The letter grading system used consists of seven grades, i.e. A (85-100), A- (80-84), B+ (75-79), B (70-74), B- (65-69), C+ (60-64) and C (55-59).

Student achievement in the apprenticeship course is also represented by a final score derived from combining the assessment by worksite mentor and supervising lecturer or so-called the final score; the final score is obtained by integrating the results of the two assessment methods above and then being divided by five, as shown in the following equation.

$$
\text { Equation }=\frac{3 \mathrm{EP} 11+2 \mathrm{EP} 12}{5}
$$

(Source: Apprenticeship Manual of Industrial Technology Study Programme)

Nevertheless, the assessment methods mentioned above cannot precisely display various competencies acquired by students during the apprenticeship programme. Combinations of scores or numerical scales cannot capture every single practical skill a student develops during apprenticeship. In fact, different students can acquire different skills, and thus scores and grades cannot give a precise description of their qualifications. Therefore, the use of numerical scores should be added with narrative descriptions which can showcase student achievement thoroughly.

\section{Developing an Apprenticeship Assessment Tool Suitable for the Diploma Supplement}

In order to help higher education institutions to adopt the Diploma Supplement, an appropriate tool for assessing student performance during apprenticeship should be developed. The instrument should be able to describe precisely the competencies each student acquires as an apprentice. A narrative description of student performance can provide rich qualitative data needed for evaluation, which are also more readable and more transparent. This description contains the information needed for issuing the Diploma Supplement.

Students holding the Diploma Supplement are more likely to have easier access to opportunities for employment because their competitiveness in the job market will improve. 
As a document accompanying a higher education diploma, the Diploma Supplement will provide a standardised description containing information on the content and status of the competencies gained during the apprenticeship programme. The document contains several sections of information, namely the identity of the holder, the originating institution, the level of the qualification, the contents and results achieved and the certification of the supplement. The Diploma Supplement must provide informed judgements on qualifications that can be easily understood in other educational and professional contexts [8].

It is necessary to develop a suitable measuring instrument for performing a realistic assessment that can display the exact job-related skills and competencies students have gained during apprenticeship. The assessment process can compile acceptable evidence of how well students perform and to what extent their achievement meets workforce requirements. Therefore, student achievement should be presented unmistakably clear to increase their competitiveness and employability [9]. Higher education institutions should clearly outline the employability skills of their graduates to open up more doors to opportunity and success in the labour market [10].

4. Components of the Apprenticeship Assessment Tool

The developed assessment tool for supporting the Diploma Supplement is described in Figure 1.

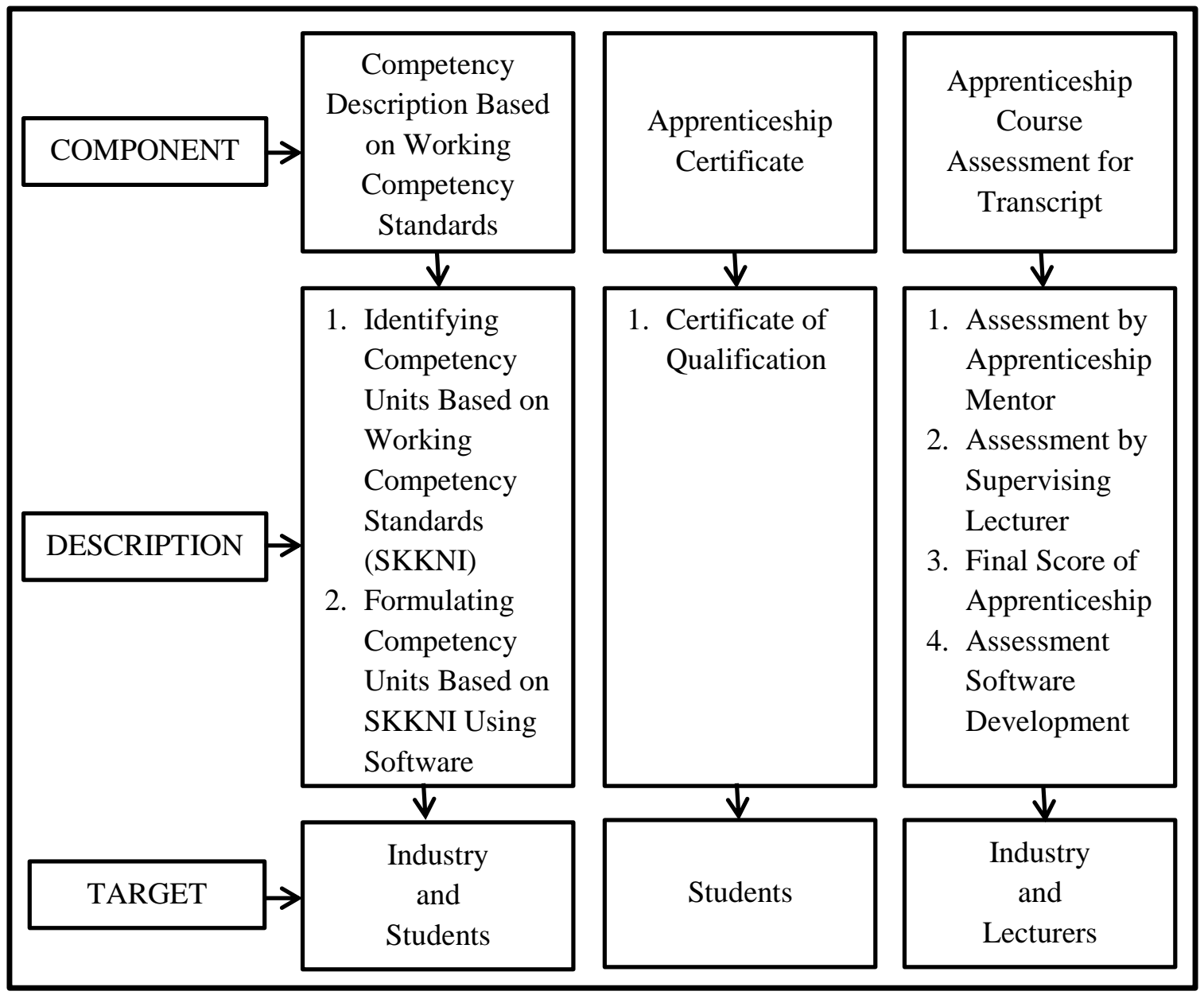

Figure 1. Apprenticeship assessment tool as the developed product 
The difference between the developed measuring instrument and the commonly used assessment tool lies in the utilisation of descriptors. Unlike the typical assessment tool which represents student achievement with scores or grades, the developed instrument can precisely display various competencies acquired by students in narrative form. Narrative-based evaluation can outline every single practical skill a student develops using detailed descriptors. The assessment tool developed is in the form of software to facilitate apprenticeship mentors in describing in details the performance of students and the competencies gained. The supervising lecturers also benefit from the competency descriptors. The descriptors are beneficial to lecturers in evaluating student performance and assigning grades for the transcript [11].

Students undertaking the apprenticeship programme should be accurately assessed on their knowledge, skills and performance. The accuracy of the assessment suggests that the scores given are reliable and valid [12]. Even though the description of competencies is not legally recognised, it is sufficient to give convincing evidence of students' capability. If the students wish to obtain legal and national recognition, they should earn certificates issued by the National Profession Standardisation Agency (BNSP).

\section{Research Method}

1. Research Design

This study used the research and development model. The research and development model aims to develop a particular product and test its effectiveness [13]. The product is developed to solve problems in the teaching and learning process [14]. In this study, the research and development was conducted to develop an instrument for assessing student performance during apprenticeship. The acceptability of the developed assessment tool was validated by subject matter experts, apprenticeship organisers, policymakers and lecturers. The product was also tried out in companies offering apprenticeship programmes. The ADDIE model was the research and development model upon which the present study was based.

\section{Product Development Procedure}

A procedure is a series of steps implemented to achieve a certain goal or complete a product [15]. This research and development was done through a 5-step procedure (see Figure 1).

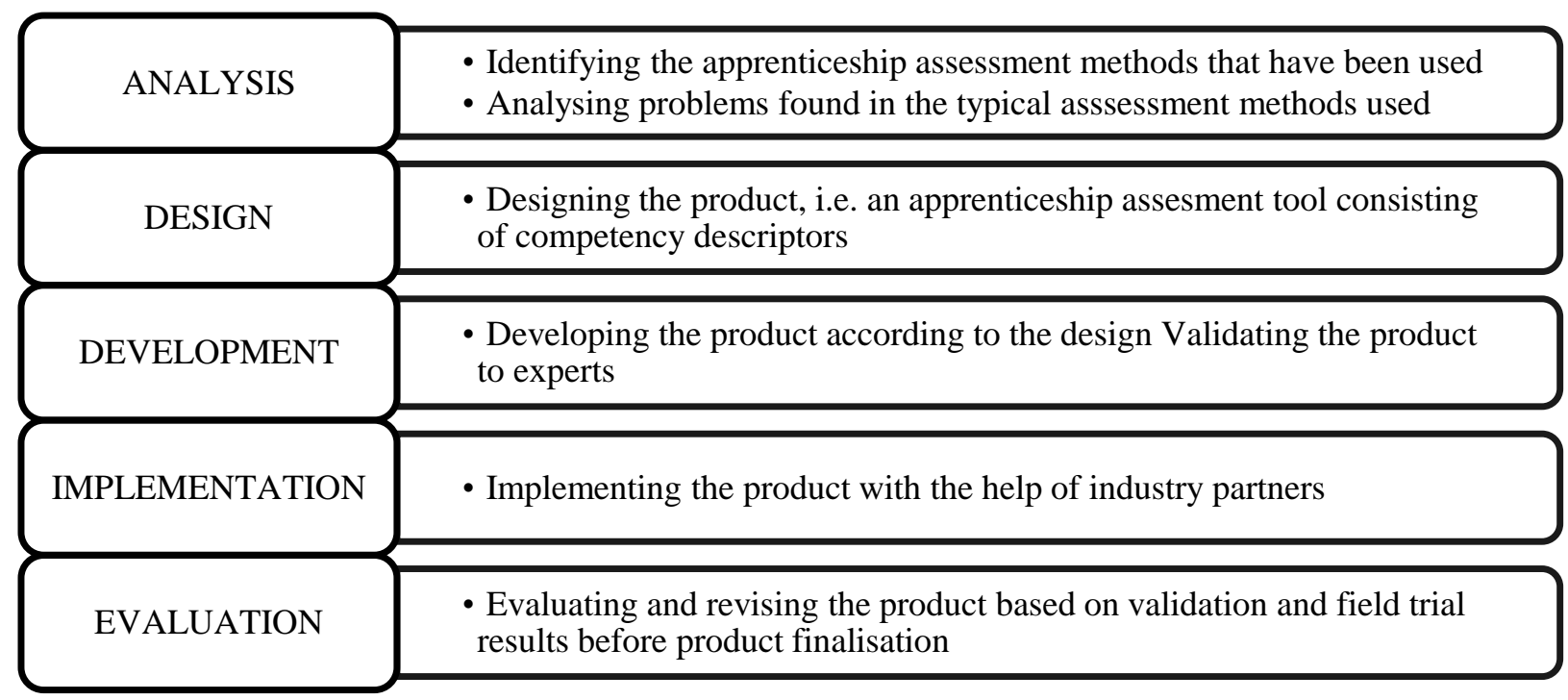

Figure 2. ADDIE Model 
The research was carried out at the Study Programme of Fashion Design, Department of Industrial Technology, Faculty of Engineering, State University of Malang, Malang. The fivestep ADDIE model was adopted accordingly to meet the need of this research in producing an educational product. The final product was an assessment tool composed of competency descriptors for apprentices.

\section{Data Collection Method}

Data were gathered through surveys, focus group discussions, documents, interviews and questionnaires. Information on competencies gained during apprenticeship was collected by conducting surveys and interviews and examining relevant documents. Focus group discussions were done to explore further information regarding the validated product. Closed questionnaires were also used to get data about the developed product.

\section{Data Analysis Method}

Data were analysed using both a qualitative and quantitative approach. The qualitative data were the descriptors of competencies. The results of the analysis became the basis for designing software for assigning competency descriptors. The product was validated by experts, revised and then tried out. Data on the acceptability of the product were processed by a quantitative descriptive approach.

\section{Results and discussion}

The development of the assessment tool aimed to bring positive benefits for students who have undertaken the apprenticeship programme. The provision of a standardised description of competencies gained during apprenticeship can increase competitiveness and enhance employment prospects. Not only for students, but the narrative description of competencies is also beneficial for supervising lecturers and apprenticeship mentors.

The narrative description of competencies is essential for issuing the Diploma Supplement. The Diploma Supplement is a document that can describe precisely the competencies of students in narrative form. In the world of work, a detailed description of the content and status of achievement and qualification will improve student employability. However, this description of competencies is not legally recognised. If the students wish to obtain legal and national recognition, they should earn certificates issued by the National Profession Standardisation Agency (BNSP).

\section{Conclusion}

The performance of students during apprenticeship is commonly assessed using the letter grading system (A, A-, B +, B, B-, C +, C, D, and E). This form of assessment is considered unsatisfactory to showcase various competencies they have acquired during apprenticeship. The scores and grades in the academic transcript should be added with narrative descriptions to provide detailed information on student achievement and competencies. Such descriptions are more valid to be presented in the Diploma Supplement.

The difference between the developed measuring instrument and the commonly used assessment tool lies in the utilisation of descriptors. Unlike the typical assessment tool which represents student achievement with scores or grades, the developed instrument can precisely display various competencies acquired by students in narrative form. Narrative-based evaluation can outline every single practical skill a student develops using detailed descriptors. The assessment tool developed is in the form of software to facilitate apprenticeship mentors in describing in details the performance of students and the competencies gained. The provision of a standardised description of competencies gained during apprenticeship can increase competitiveness and enhance 
employment prospects. Not only for students, but the narrative description of competencies is also beneficial for supervising lecturers and apprenticeship mentors.

\section{References}

[1] Direktorat Jenderal Pembelajaran dan Kemahasiswaan Kementerian Riset Teknologi dan Pendidikan Tinggi Republik Indonesia 2015 Surat Keterangan Pendamping Ijazah

[2] Narimo, S Membangun Daya Saing Lulusan Pendidikan (Akuntansi) Tinggi Bertumpu pada Penguatan Kurikulum Berbasis KNNI Prosiding Seminar Nasional Pendidikan Akuntansi dan Keuangan p 433

[3] Porter M E 1990 The CompetitiveAdvantage of Nation (New York: The Free Pass)

[4] Ali M 2013 Analisis Kesiapan SMK RSBI dalam Peningkatan Daya Saing Lulusan Jurnal Kependidikan 43 p 85

[5] Wahyoedi S 2000 The New Growth Theory: Peranan Ilmu Pengetahuand an Investasi Sumber Daya Manusia sebagai Pemacu Pertumbuhan Eknomi (Jakarta: UKRIDA Press)

[6] Frinces 2011 Persaingan dan Daya Saing: Kajian Strategis Globalisasi Ekonomi (Yogyakarta: Mida Pustaka)

[7] Katalog Jurursan TI

[8] Berg C and Teichler U 1988 Unveiling the Hidden Information in Credentials: A Proposal to Introduce a "Supplement to Higher Education Diplomas" Higher Education in Europe $13 \mathrm{p}$ 18

[9] Nickolaus R 2012 Vocational Skills and Competencies Made Visible (Bonn: Federal Ministry of Education and Research (BMBF) Training Policy Division) p 4

[10] Wang Y F and Tsai C T 2014 Employability of Hospitality Graduates: Student and Industry Perspectives Journal of Hospitality \& Tourism Education $\mathbf{2 6} \mathbf{1 2 5}$

[11] Falender C A and Shafranske 2011 The Importance of Competency-based Clinical Supervision and Training in the Twenty-first Century: Why Bother? J Contemp Psychother $42 \mathrm{p} 130$

[12] Suhairom N, Musta'amal A H, Amin N F M and Johari N K A 2014 The Development of Competency Model and Instrument for Competency Measurement: The Research Methods Procedia Social and Behaviorial Sciences 152 p 1302

[13] Sugiyono 2011 Metode Penelitian Kuantitatif, Kualitatif, dan R\&D (Jakarta: Alfhabeta)

[14] Tegeh I M and Kirna I M 2013 Pengembangan Bahan Ajar Metode Penelitian Pendidikan dengan Model ADDIE Jurnal Ika 1114

[15] Borg W R \& Gall M D 1989 Educational Research: An Introduction Fifth Edition (New York: Longman) 


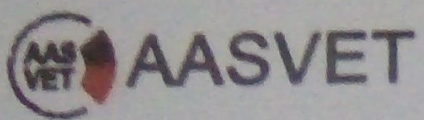

\section{CERTIFICATE OF PARTICIPATION}

This is to certify that

\section{Agus Hery Supadmi Irianti}

has presented a paper entitled:

"Developing an Apprenticeship Assessment Tool to Improve the Competitiveness of Fashion Design Graduates" in the 14 AASVET Conference under the theme "Improving the Role of TVET on the 4 th Industrial Revolution", held by Graduate School Yogyakarta State University in Prime Plaza Hotel, Yogyakarta, Indonesia from $7^{\text {th }}-9^{\text {th }}$ September 2018.

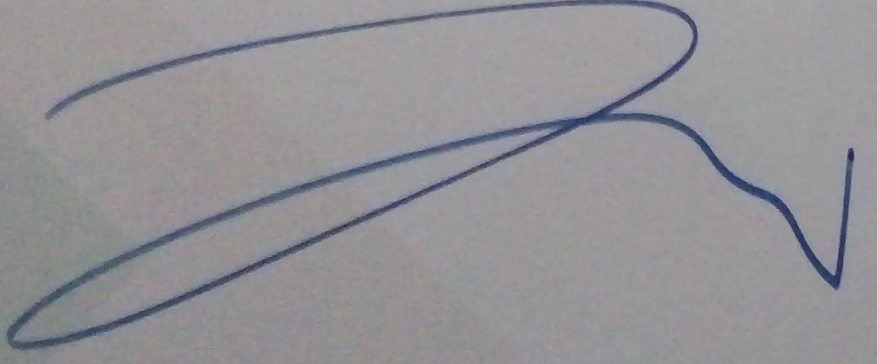

Prof. Dr. Marsigit, M.A. Director of Graduate School Yogyakarta State University

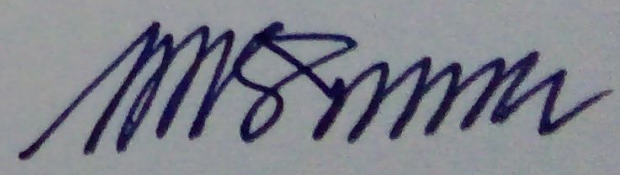

Dr. Moch. Bruri Triyono, M.Pd. Chair of International Conference Organizing Commitee 